\title{
Аналіз безпосередніх результатів ендоваскулярного ендопротезування інфраренальноі частини аорти та лікування періопераційних ускладнень
}

\author{
О. А. Власенко
}

Національний інститут хірургії та трансплантології імені О. О. Шалімова НАМН України, м. Київ

\section{Analysis of immediate results of endovascular endoprosthesis of infrarenal aorta and treatment of perioperative complications}

\author{
O. A. Vlasenko
}

Shalimov National Institute of Surgery and Transplantology, Kyiv

\section{Реферат}

Мета. Проаналізувати результати ендоваскулярного ендопротезування інфраренальної частини аорти та періопераційні ускладнення в залежності від типу конструкції стент-графту.

Матеріали і методи. Основою роботи є аналіз результатів лікування 133 пацієнтів, проведеного за період з листопада 2005 по листопад 2018 р. в ендоваскулярному відділенні Інституту. Біфуркаційні ендопротези «Excluder» Gore, що мають інфраренальну фіксацію, імплантували 85 (63,9\%) пацієнтам (1-ша група). 3 листопада 2013 р. 48 (36,1\%) пацієнтам були імплантовані ендопротези нового покоління «Endurant-II» Medtronic з додатковою металевою структурою, яка забезпечує супраренальну фіксацію (2-га група).

Результати. На підставі аналізу безпосередніх результатів лікування констатовано, що із 133 паціентів жоден не помер і у жодного не виникли небезпечні для життя ускладнення за умови індивідуального підбору ендопротезу з урахуванням анатомії аневризми. Технічно успішною імплантація була у 98,8\% паціентів 1-ї та у 100\% пацієнтів 2-ї групи. Частота повторних втручань у найближчому післяопераційному періоді становила 2,25\%.

Висновки. Стент-графти останнього покоління, які можливо застосовувати у пацієнтів зі складною анатомією інфраренальної частини аорти, забезпечують значне зниження крововтрати завдяки вдосконаленій системі доставки. Технічний успіх і тривалість операції залежать не тільки від типу ендопротеза, а й від досвіду оператора як загального, так і з використання конкретної моделі.

Ключові слова: аневризма інфраренальної частини аорти; ендопротезування аорти; ендопротікання.

\section{Abstract}

Objective. The results of endovascular endoprosthesis of infrarenal aorta and perioperative complications, depending on the construction type of a stent-graft.

Materials and methods. The work was based on the results of treatment analysis in 133 patients, conducted in period from November 2005 to November $2018 \mathrm{yr}$ in endovascular department of the Institute. Bifurcation endoprostheses «Excluder» Gore, owing infrarenal fixation, were implanted in 85 (63.9\%) patients (Group I). From November 2013 yr to 48 (36.1\%) patients the endoprostheses of a new generation «Endurant-II» Medtronic with additional metallic structure, guaranteeing suprarenal fixation (Group II), were implanted.

Results. Basing on analysis of immediate results of treatment there was postulated, that from 133 patients no one died and in no one the life-threatening morbidity have occurred in a case of individual selection of endoprosthesis done in accordance to the aneurysm anatomy present. Technically successful implantation was in $98.8 \%$ patients of Group I and in 100\% patients of the Group II. The reoperation rate in immediate postoperative period have constituted $2.25 \%$

Conclusion. Stent-grafts of last generation, which may be applied in patients with complex anatomy of infrarenal aorta, guarantee a significant lowering of a blood loss due to the improved delivering system used. Technical success and the operation duration depend on not only the endoprosthesis type, but as well as on operator experience - a general one and while application of a certain model.

Keywords: aneurysm of infrarenal aorta; endoprosthesis of aorta; endoleakage.

Ендоваскулярне ендопротезування має низку незаперечних переваг, які розширюють можливості оперативного лікування пацієнтів з аневризмою інфраренальної частини аорти (АІЧА), і водночас не позбавлене недоліків, одним з яких є ризик неповного виключення аневризми 3 постійним припливом крові в аневризматичний мішок (AM), тобто ендопротікання (ЕП) - специфічного ускладнення ендопротезування аорти [1]. Певні типи ЕП несуть у собі небезпеку швидкого і значного збільшення АМ, що може призвести до його розриву [2].
Тип ЕП визначають за його джерелом і кількістю артерій, з яких відбувається заповнення АМ (рис. 1).

У разі ЕП І типу кров під великим тиском через один або кілька каналів потрапляє в АМ з аорти або здухвинних артерій і відтікає через поперекові (ПА) або нижню брижову (НБА) артерії, створюючи в АМ тиск, який за величиною відповідає системному, що спричиняє збільшення АМ з високою ймовірністю розриву.

Основними предикторами розвитку первинного ЕП I типу є складна анатомія аневризми, у першу чергу дуже 


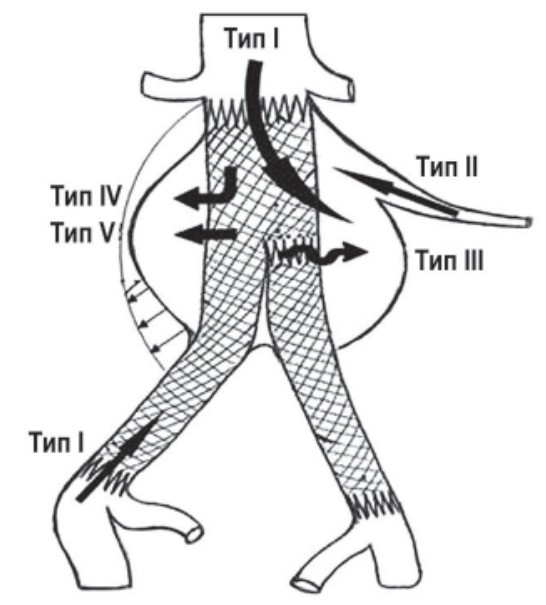

Puc. 1 .

Типи ендопротікання:

I - ендопротікання з проксииальної або дистальної зони фіксачї̈ ендопротеза; II - ретрограднии затік з перекритих протезом артерій; III - ендопротікання внаслідок структурної дезорганізаціӥ ендопротеза; IV - порозність ендопротеза

(проявляється в периі 30 днів після імплантаціi); V-ендотензія.

коротка i/або ангульована ії проксимальна шийка, конічна форма шийки, товщина тромботичних мас у місці проксимальної фіксації більше 2 мм, а також мальпозиція стент-графту, зайва його постдилатація, оверсайсінг більше 20\%. Ризик виникнення ЕП І типу також пов'язаний з конструкційними особливостями і типом фіксації ендопротеза. ЕП I типу, що розвивається у віддаленому післяопераційному періоді, $є$ наслідком ремоделювання аневризми та міграції стент-графтів або прогресуючого розширення інфраренальної шийки. Стент-графти, фіксація яких забезпечується лише радіальною стійкістю, більш схильні до міграції у віддаленому періоді, ніж протези з гачками або з додатковою непокритою супраренальною частиною.

У разі ЕП ІІ типу відбувається ретроградне заповнення АМ частіше з ПА і/або з НБА, більш рідко - з сакральних, гонадної або ниркової артерій. Цей тип ЕП також може призводити до збільшення і розриву АМ, проте не так часто і не так швидко, як в умовах ЕП I і ІІІ типів - відповідно 0,5 і 3,4\% спостережень [3]. ЕП ІІ типу наразі є однією з головних проблем технології ендопротезування аневризми аорти, оскільки це ускладнення виникає найбільш часто, а лікувати його найбільш складно технічно [4].

Роз'єднання модулів стент-графтів (ЕП ІІІ типу) - рідкісне ускладнення, білыш характерне для протезів першого покоління, виникає внаслідок меншого, ніж було передбачено, перекриття основної частини і контрлатеральної ніжки. Даний тип ЕП призводить до прямого сполучення між аортою і АМ, створюючи в ньому тиск, який за величиною відповідає системному. Так само, як і ЕП І типу, ЕП III типу необхідно усувати в максимально стислі строки після виявлення [5]. На відміну від ЕП І типу, за наявності ЕП ІІІ типу тиск в АМ різко підвищується, що створює найбілыший ризик його розриву, і ніколи не зникає самостійно. Для усунення дислокації виконують імплантацію додаткового модуля стент-графту.
EП IV типу виникає внаслідок порозності покриття стент-графту. Візуалізується за допомогою контрольної ангіографії під час його імплантації як хмара, що слабко контрастується в AM. Істинний IV тип ЕП рідко спостерігають під час імплантації сучасних конструкцій ендопротезів, ускладнення виникає безпосередньо після імплантації, коли організм пацієнта насичений антикоагулянтами, не має явного джерела і зникає спонтанно в найближчому післяопераційному періоді. Якщо EП IV типу не зникає протягом більше 30 днів, завжди необхідно виключити наявність ЕП іншого типу [6].

Окремо виділяють також ендотензію, що призводить до збільшення АМ без визначеного будь-якими методами дослідження ЕП. Деякі автори вважать ендотензію V типом ЕП $[1,6]$.

До нечастих, але таких, що мають клінічне значення, періопераційних ускладнень після ендоваскулярного ендопротезування інфраренальної частини аорти (ЕЕІЧА) відносять: тромбоз бранш ендопротеза, тромбоз артерій, що відходять від аорти, зокрема артерій нижніх кінцівок, ненавмисне накриття ниркових артерій при імплантації ендопротеза, ішемічний коліт, сідничну переміжну кульгавість, імпотенцію, розвиток контрастіндукованої нефропатії, інфікування ендопротеза [7-11].

Мета дослідження: проаналізувати результати ЕЕІЧА та періопераційні ускладнення в залежності від типу конструкції стент-графту.

\section{Матеріали і методи дослідження}

В основу роботи покладено аналіз результатів лікування 133 хворих, проведеного за період з листопада 2005 по листопад 2018 р. в ендоваскулярному відділенні Інституту. Біфуркаційні ендопротези "Excluder" Gore, що мають інфраренальну фіксацію, імплантували 85 (63,9\%) пацієнтам (1-ша група). Починаючи з листопада 2013 р. 48 (36,1\%) пацієнтам імплантували протези нового покоління «Endurant-II» Medtronic з непокритою додатковою металевою конструкцією, яка забезпечує супраренальну фіксацію (2-га група).

Із 133 пацієнтів, включених у дослідження, чоловіків було 133 (94\%), жінок - 7 (6\%). Вік пацієнтів коливався від 50 до 82 років: 11,4\% пацієнтів мали вік до 60 років; 48,6\% - від 61 до 70 років, 36,5\% - старше 70 років, 3,5\% - старше 80 років. Діаметр аневризми в середньому становив $(59,4 \pm 7,5)$ мм.

Оцінюючи найближчі результати операції (перші 30 діб), враховували технічну успішність імплантації ендопротеза (точне позиціонування і співвідношення його компонентів), наявність ЕП, особливо I і ІІІ типів, що призводять до швидкого збільшення АМ, а також інтраопераційні та ранні післяопераційні ускладнення, об'єм крововтрати, тривалість втручання, наявність серцево-судинних ускладнень, необхідність повторних втручань у ранньому післяопераційному періоді.

\section{Результати}

Вивчивши отримані дані, ми порівняли найближчі результати лікування пацієнтів 1-ї та 2-ї груп. Застосування ендопротезів з супраренальною фіксацією уможливило 


\begin{tabular}{|c|c|c|}
\hline \multirow[t]{2}{*}{ Результат } & \multicolumn{2}{|c|}{ Вид ендоендопротеза } \\
\hline & $\begin{array}{l}\text { «Excluder»/«Excluder-C3» } \\
\text { (1-ша група) }\end{array}$ & $\begin{array}{l}\text { "Endurant-II» } \\
\text { (2-га група) }\end{array}$ \\
\hline Інтраопераційна летальність & - & - \\
\hline Технічний успіх імплантації & $84(98,82 \%)$ & $48(100 \%)$ \\
\hline Тривалість ендоваскулярного етапу операції, хв & $86,21 \pm 12,63^{*}$ & $54,23 \pm 7,43$ \\
\hline Тривалість флюороскопії, хв & $37 \pm 10,3 *$ & $19 \pm 4,6$ \\
\hline Об'єм крововтрати, мл & $224,2 \pm 23,5^{*}$ & $113 \pm 25,7$ \\
\hline Всього ... & $78 / 7$ & 48 \\
\hline * - статистично значущі відміннс & янні з 2-ю групою ( $p<0$, & \\
\hline
\end{tabular}

розширення показань до ЕЕІЧА у пацієнтів з короткою, кальцинованою і тромбованою проксимальною шийкою аневризми. Після операції пацієнти перебували в стаціонарі в середньому 6,1 дня. У найближчому післяопераційному періоді жоден із пацієнтів не помер. Також ужодного пацієнта не виникли серцево-судинні ускладнення. Реінтервенцію виконали 3 пацієнтам.

У пацієнтів 2-ї групи була значно коротша як загальна тривалість ендоваскулярного етапу втручання, так і тривалість флюороскопії, а також був меншим об'єм крововтрати, що пов'язано з поліпшеною системою доставки за рахунок гідрофільного покриття і вдосконалених гемостатичних клапанів інтродюсерів (табл. 1). На скорочення тривалості втручання вплинули два основні фактори: білыш проста система імплантації та великий досвід операторів. Тривалість перебування пацієнтів у стаціонарі у разі використання різних видів ендопротезів не відрізнялась.

Одним із прогнозованих і найбільш обговорюваних факторів ризику розвитку такого несприятливого результату, як ЕП IA типу, є так звана несприятлива проксимальна шийка аневризми [12 - 14]: довжина менше 15 мм, виражена ангуляція, конічна форма, наявність виражених тромботичних нашарувань і кальциноз, широка шийка. Саме в місці проксимальної імплантації ендопротез найбільше схильний до зсуву внаслідок неадекватної фіксаціï, а перераховані анатомічні особливості передбачають великий досвід і підготовку хірургічної бригади для точного позиціонування, правильної імплантації і запобігання виникненню ускладнень $[15,16]$.

3 огляду на рекомендації щодо анатомічних характеристик аорти для ендопротезування, ми переважно відбирали пацієнтів, у яких проксимальна шийка мала довжину 15 мм або більше, не було вираженого їі тромбозу і градієнта діаметра, змін здухвинних артерій. Однак з накопиченням досвіду ендопротезування, а також вдосконаленням технологій, появою ендопротезів з можливістю репозиціонування проксимальної частини або з супраренальною фіксацією (в нашому спостереженні це ендопротези «Excluder-C3» Gore i «Endurant-II» компанії «Medtronic»), анатомічні показання до ЕЕІЧА ми дещо розширили: допустима довжина проксимальної шийки від 10 мм, діаметр до 32 мм, ангуляція до 75익. Для запобігання дистальній міграції та покращення проксимального з'єднання ендопротези останнього покоління («Endurant-II») мають непокриту проксимальну фіксуючу частину, що дає можли-

\begin{tabular}{|c|c|c|c|c|}
\hline \multirow{4}{*}{ Тип ЕП } & \multicolumn{4}{|c|}{$\begin{array}{l}\text { Типи ЕП, діагностовані } \\
\text { в безпосередньому післяопераційному } \\
\text { періоді у пацієнтів, } \\
\text { яким використовували різні види } \\
\text { ендопротезів }\end{array}$} \\
\hline & \multicolumn{4}{|c|}{ Вид ендопротеза } \\
\hline & \multicolumn{2}{|c|}{$\begin{array}{l}\text { «Excluder» } \\
(n=85)\end{array}$} & \multicolumn{2}{|c|}{$\begin{array}{l}\text { «Endurant-II» } \\
\quad(n=48)\end{array}$} \\
\hline & абс. & $\%$ & абс. & $\%$ \\
\hline IA & 6 & 7,1 & - & - \\
\hline IB & 8 & 9,4 & 3 & 6,3 \\
\hline II & 17 & 20 & 12 & 25 \\
\hline III & 1 & 1,2 & - & - \\
\hline IV та V & - & - & - & - \\
\hline Всього ... & 32 & 37,6 & 14 & 29,2 \\
\hline
\end{tabular}

вість позиціонувати їх в інтервісцеральній частині аорти вище рівня ниркових артерій.

Усього було прооперовано 28 хворих з короткою проксимальною шийкою, коли ії довжина становила $10-15$ мм, у середньому $(13,57 \pm 1,43)$ мм. Ендопротези «Exluder» імплантували 22 (78,6\%) із 28 хворих, причому 7 (25\%) хворим, у яких коротка шийка поєднувалась 3 вираженою іiі ангуляцією, - ендопротези «Exluder-С3» 3 можливістю репозиціонування проксимальної частини шляхом зворотного збирання, ендопротези «EndurantII» імплантували 6 (21,4\%) хворим.

Мінімальна довжина шийки, за якої використовували ендопротез «Exluder», була 12 мм, «Endurant-II» - 10 мм. Щодо 1 пацієнта, у якого була ангульована (60) конічна проксимальна шийка аневризми довжиною 12 мм, прийняли рішення про виконання ЕЕІЧА у зв'язку з протипоказаннями до виконання відкритої реконструкції аорти (тяжкий аортальний стеноз і пневмоконіоз).

Значуще ЕП IА типу спричинила дистальна міграція ендопротеза під час його розкриття через невідповідність геометрії ендопротеза і аорти і неможливість репозиціонування. Ускладнення може бути кориговане імплантацією подовжувача проксимальної частини, рідше - додатковою баллонною дилатацією.

Із 28 хворих у 5 аневризма мала коротку шийку з вираженою iї ангуляцією $\left(50-70^{\circ}\right)$. Ендопротез «Exluder» імплантовано 4, «Endurant-II» - 1 хворому. У всіх 4 пацієнтів 1-ї групи з короткою і ангульованою проксимальною шийкою під час контрольної ангіографії було вияв- 


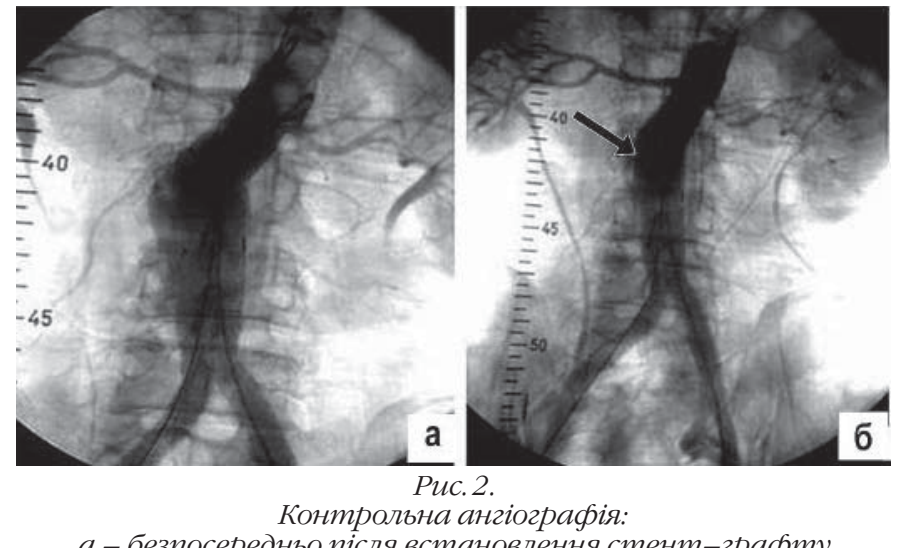

а - безпосереднъо після встановлення стент-графту (ЕП ІА типу з швидким заповненням всієї порожнини АМ); б - після імплантащї подовжувача проксимальної частини (незначне ЕП у вилляді каналу по правому боці ендопротеза).

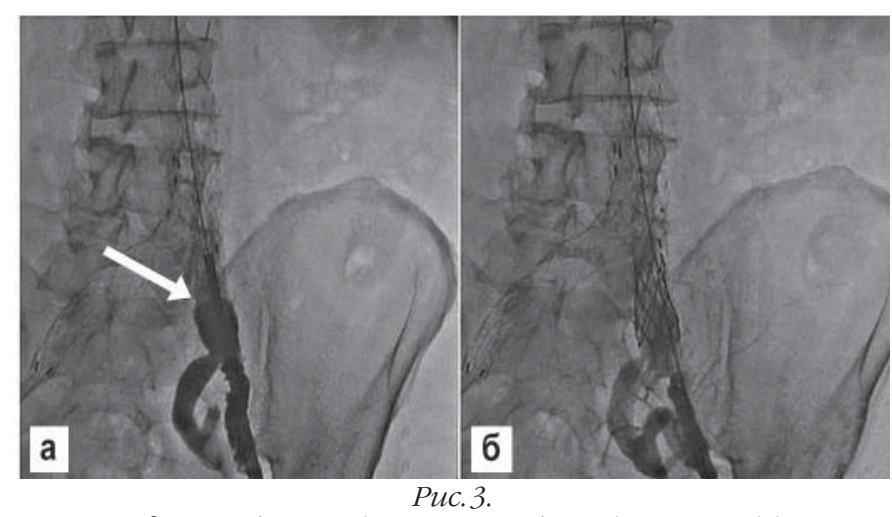

Ендопротікання (вказано стрілкою) ІВ типу (a); інплантований непокритий стент, розширении за допомогою балона, до гирла внутрішнъої здухвинної артерій (б).

лено ЕП ІА типу. Виникнення значного ЕП ІА типу діагностували ще у 1 пацієнтки, у якої була аневризма 3 початковою довжиною проксимальної шийки 22 мм і ангуляцією $60^{\circ}$. У всіх хворих дане ускладнення було успішно усунено імплантацією подовжувача проксимальної частини.

У пацієнтів, яким були імплантовані ендопротези «Excluder-C3» та «Endurant-II», ЕП IA типу безпосередньо на момент закінчення операції і за період спостереження не виявлено завдяки додатковій проксимальній непокритій частині та можливості репозиціонування після відкриття перших трьох ланок ендопротеза.

Типи ЕП безпосередньо після імплантації різних видів ендопротезів відображені в табл. 2 .

В усіх 6 спостереженнях ЕП ІА типу було кориговане встановленням додаткового проксимального подовжувача (5) або за допомогою баллонної дилатації (1). ЕП ІВ типу в обох групах також було усунено імплантацією дистальних подовжувачів (у 7 хворих 1-ї групи та у 2 хворих 2-ї групи) або баллонною дилатацією (у 1 хворого1-ї групи та у 1 хворого 2-ї групи). За частотою ЕП ІІ типу між порівнюваними групами статистично значущої відмінності не спостерігали.

У 1 пацієнта 1-ї групи за наявності короткої (10 мм) проксимальної шийки аневризми та АМ діаметром 59 мм безпосередньо після встановлення стент-графту за допомогою контрольної ангіографії було виявлено виражене ЕП ІА типу, після чого імплантовано подовжувач ший- ки, інтенсивність ЕП значно зменшилася (рис. 2). На 3-й день за результатами ультразвукового дуплексного сканування (УЗДС) установлено ЕП лінійної форми до 8 мм в діаметрі з відтоком у крижову артерію та зменшення діаметра АМ до 56 мм. Повторним УЗДС збільшення АМ не виявлено. Хворий був виписаний. Через 4 міс за даними мультиспіральної комп'ютерної томографії (МСКТ) ЕП IA типу немає, діаметр АМ 54 мм, але виявлено ЕП III типу через розходження основної частини та подовжувача проксимальної частини, у зв'язку з чим хворому імплантовано ще один проксимальний подовжувач.

У хворого початково був фактор ризику виникнення ЕП І типу з огляду на коротку конусоподібну проксимальну шийку аневризми, але з урахуванням наявності супутнього комбінованого аортального пороку з переважанням стенозу (систолічний градієнт на аортальному клапані 88 мм рт. ст.), хронічної обструктивної хвороби легенів (пневмоконіоз), дихальної недостатності II ступеня, сечокам'яної хвороби, доброякісної гіперплазії передміхурової залози II стадії, хронічної ниркової недостатності І стадії, варикозної хвороби нижніх кінцівок хворому було вирішено першим етапом виконати ЕЕІЧА, а через 3 міс - протезування аортального клапана.

За наявності ЕП ІВ типу лікування таке ж, як за наявності ЕП ІА типу, але частіше ефективні балонна ангіопластика і імплантація непокритого стента.

Iз 133 оперованих хворих ЕП ІІ типу під час контрольної ангіографії інтраопераційно спостерігали у 29, причому у 12 з них за даними УЗДС на 3-тю добу ЕП будь-якого типу не виявлено, у 16 підтверджено ЕП II типу, у 1 виявлено ЕП ІІІ типу. Дані відмінності можна пояснити високою частотою самостійного зникнення ЕП ІІ типу в короткі терміни, а також складністю диференціювання ЕП II i III типу тільки за результатами ангіографії.

Одним із значущих періопераційних ускладнень є тромбоз однієї з бранш ендопротеза або тромбоз стегно-підколінного сегмента [18, 19].

У цілому тромбоз виник у 6 (4,3\%) хворих. У 2 хворих тромбоз виник під час виконання операції (обидва хворі з 1-ї групи), у 2 - в 1-шу добу після операції (1 - 3 1-ї групи, 1 - 32 2-і). Ще у 2 хворих (1 - 31 -ї групи, 1 - 3 2-і) діагностовано неоклюзуючий тромбоз у віддаленому періоді. У разі невикористання додаткових подовжувачів ніжки тромбозу не виявляли, а у разі їх використання тромбоз виник у $6(15,4 \%)$ із 39 спостережень ( $=0,001)$, що свідчить про підвищений ризик виникнення тромбозу у разі використання багатокомпонентних ендопротезів. Частота виникнення тромбозу не залежала від виду ендопротеза. У 1 пацієнта тромбоз бранші ендопротеза, який виник у момент імплантації контрлатеральної ніжки, був усунений безпосередньо після контрольної ангіографії шляхом ендоваскулярної тромбектомії із застосуванням балон-катетера.

У 1 пацієнта під час виконання операції діагностували тромбоз поверхневої стегнової артерії. Йому виконали тромбектомію.

Виконання реінтервенції в найближчому післяопераційному періоді, за даними літератури, супроводжується підвищенням морбідності та смертності $[1,7,11,20]$. Тому 


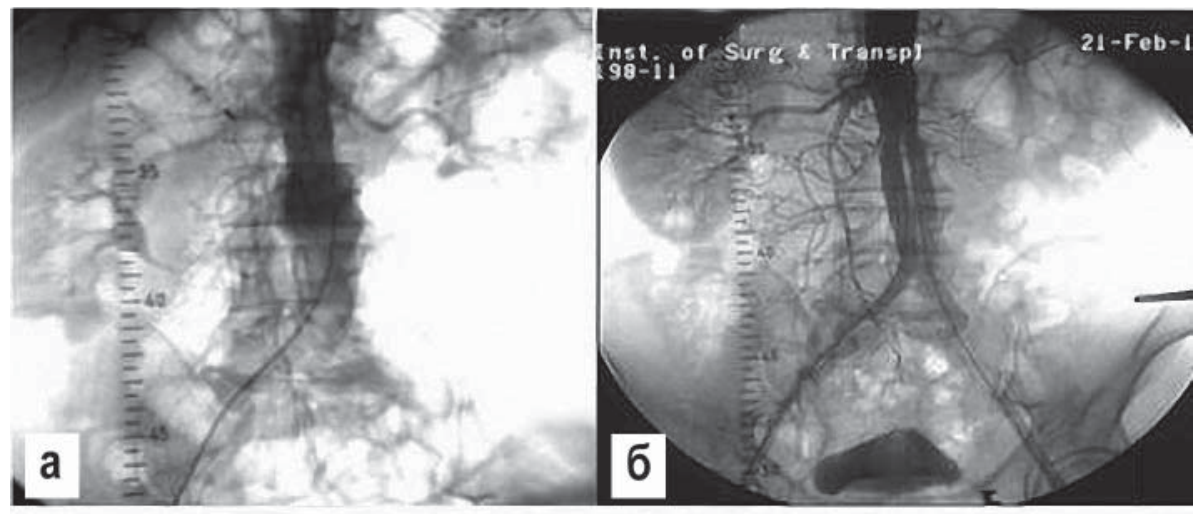

Puc. 4.

Iнтраопераційне стентування лівої ниркової артерії, накритої

ендопротезом: $a$ - аортографія на початку операції, б - аортографія після ілплантащї стент-графту (ліва ниркова артерія не контрастується); в - реканалізація лівої ниркової артеріі коронарним провідникол; г - в гирло лівої ниркової артерії заведений стент;

д - селективна артеріографія лівої ниркової артерії після інплантації стенту; е - завершальна аортографія (обидві ниркові артерії ообре заповнені).
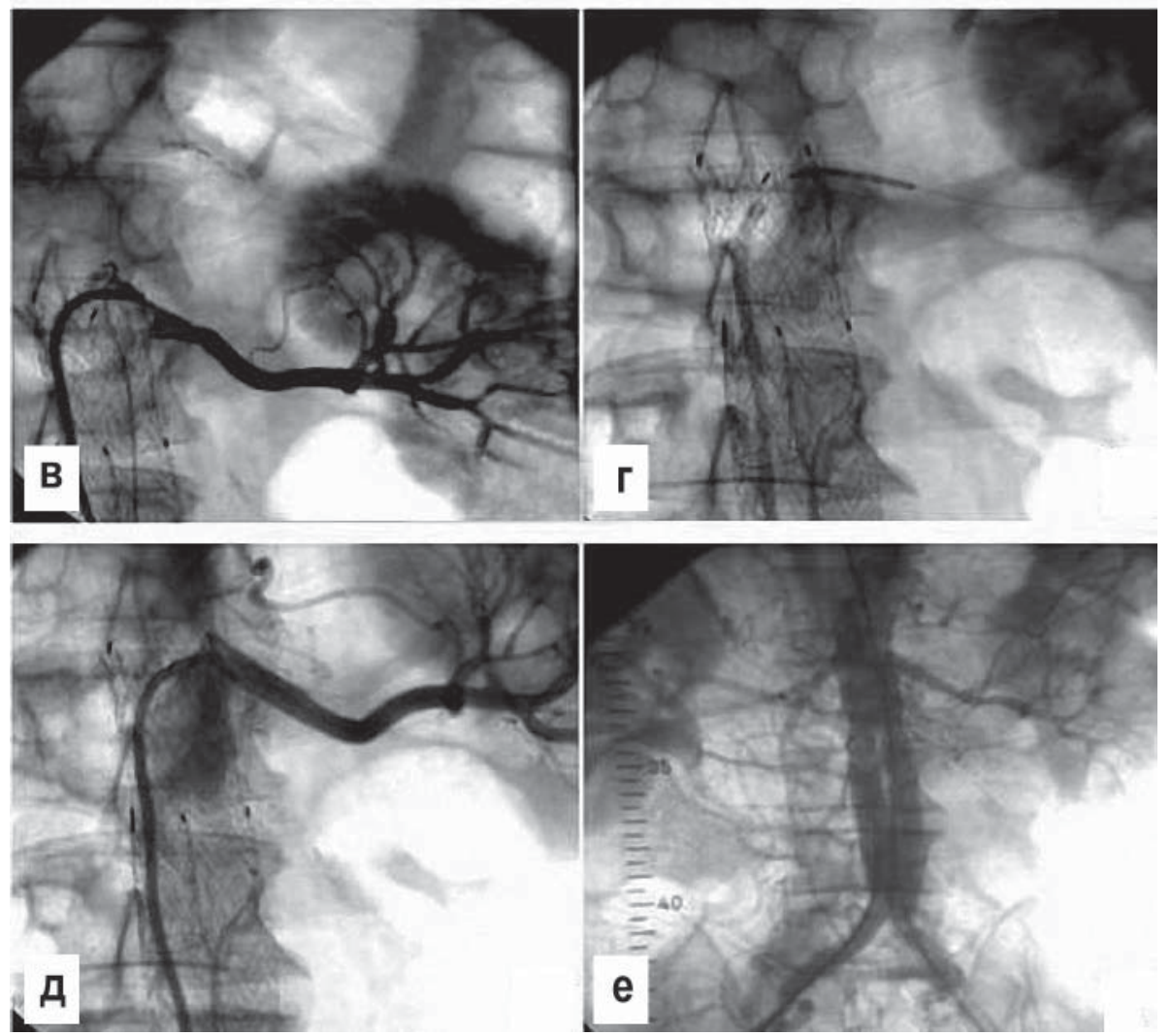

важливо виключити можливі ускладнення, які потребують виконання реінтервенції, як під час підготовки, так і під час виконання ендопротезування.

Реінтервенцію в найближчому післяопераційному періоді виконали 3 хворим. У 1 хворого через 6 год після ендопротезування виник гострий тромбоз стегно-підколінного сегмента, у 1 хворого був діагностований тромбоз бранші ендопротеза через добу після втручання. Обом хворим виконали тромбектомію під місцевим знеболюванням. У 1 хворого 1-ї групи виявили ЕП ІВ типу, у зв'язку з чим на 3-тю добу йому виконана імплантація непокритого стента дистальніше бранші з балонною дилатацією місця фіксації, що усунуло ЕП (рис. 3).

Під час ЕЕІЧА можливе ненавмисне накриття ниркових артерій покритою частиною ендопротеза. Подібне ускладнення спостерігають досить рідко - у 0,1- 3,5\% хворих за даними літератури [9, 21]. Ми діагностували таке ускладнення у пацієнта 3 короткою (15 мм) та тромбова- ною проксимальною шийкою (рис.4). Під час імплантації основної частини ендопротеза в момент його розкриття була накрита ліва ниркова артерія, що відходила дистальніше. Оскільки було використовано ендопротез «Exluder» без можливості репозиціонування проксимальної частини, ускладнення усунули реканалізацією просвіту артерії за допомогою коронарного провідника та імплантацією непокритого металевого стента з повним відновленням кровотоку по нирковій артерії.

Через 5 міс і 4 роки спостереження за результатами МСКТ стент прохідний, ознак звуження немає.

У літературі також описано спостереження білатеральної оклюзії ниркових артерій стент-графтом із супраренальною фіксацією. Дистальна тракція і спроба ендоваскулярної реканалізації з використанням феморального та брахіального доступів виявились безуспішними. У результаті пацієнтові успішно було сформовано білатеральний спленоренальний анастомоз [22]. 
Широко використовують методику паралельної імплантації аортального стент-графту та стентування ниркової артерії (методика «Chimnеу» або «димохід») у разі іiі низького відходження [23]. Дану методику ми попередньо запланували та застосували у 1 хворого.

Серед інших ускладнень сідничну переміжну кульгавість, яка продовжувалася до 14 днів та не потребувала лікування, спостерігали у 4 (33,3\%) із 12 хворих після накриття однієї з внутрішніх здухвинних артерій з ії попередньою емболізацією. Ішемічного коліту у жодного хворого не зафіксували.

\section{Обговорення}

Наш досвід ЕЕІЧА з використанням ендопротезів останнього покоління з інфраренальною та супраренальною фіксацією показав хороші найближчі і віддалені результати. Використання методики ендопротезування у пацієнтів з АІЧА та високим ризиком відкритої аневризмектомії дало змогу уникнути тяжких ускладнень, в тому числі кардіоваскулярних, і смертності. Дане втручання є методом вибору для лікування хворих, що мають високий анестезіологічний і хірургічний ризик.

На підставі аналізу безпосередніх результатів лікування досліджуваних пацієнтів можна зробити висновок про менший ризик виникнення найбільш несприятливого типу ЕП, а саме IА, у разі застосування стент-графтів 3 можливістю репозиціонування проксимальної частини - «Excluder - C3» i «Endurant-II», у тому числі у пацієнтів 3 несприятливою анатомією - короткою та ангульованою проксимальною шийкою аневризми.

ЕП I та III типу як найбільш небезпечні, що призводять до збільшення АМ, необхідно усувати у міру виявлення, застосовуючи додаткові модулі.

Виникнення ЕП ІІ типу, особливо якщо джерелом є ПА, прогнозувати складно. Частота виникнення ЕП ІІ типу не залежить від виду ендопротеза, прогноз за наявності цього ускладнення найбільш сприятливий, у більшості спостережень воно не призводить до збільшення АМ та через деякий час зникає самостійно.

EП IV та V типів як самостійну причину збільшення АM у досліджуваних хворих не спостерігали.

Враховуючи виключення з кровотоку НБА під час ЕЕІЧА, коли внутрішні здухвинні артерії залишаються функціонуючими, необхідне збереження хоча б однієї з них для запобігання розвитку ішемічного коліту.

У разі ненавмисного накриття ниркових артерій можливе виконання ендоваскулярної реваскуляризації з повним відновленням функції нирки.

\section{Висновки}

1. При аналізі безпосередніх результатів ендопротезування аорти відмічено відсутність летальності та загрозливих для життя ускладнень за умови індивідуального підбору ендопротеза з урахуванням особливостей анатомії аневризми. Всі ускладнення, що виникли в періопераційному періоді, були успішно кориговані завдяки великому досвіду різноманітних ендоваскулярних маніпуляцій та злагодженій роботі бригади ендоваскулярних та судинних хірургів.
2. Основними перевагами конструкцій ендопротезів останнього покоління є розширення можливостей їх використання у пацієнтів зі складною анатомією АІЧА, значуще зниження крововтрати за рахунок вдосконаленої системи доставки. Тривалість операції залежить не тільки від виду ендопротеза, а й від досвіду оператора як загального, так і з використання конкретної моделі.

\section{References}

1. Chaikof EL, Brewster DC, Dalman RL, Makaroun MS, Illig KA, Sicard GA, et al.. SVS practice guidelines for the care of patients with an abdominal aortic aneurysm: executive summary. J Vasc Surg. 2009 Oct;50(4):880-96. doi: 10.1016/j.jvs.2009.07.001.

2. Antoniou GA, Georgiadis GS, Antoniou SA, Neequaye S, Brennan JA, Torella F, et al. Late Rupture of Abdominal Aortic Aneurysm After Previous Endovascular Repair: A Systematic Review and Meta-analysis. J Endovasc Ther. 2015 Oct;22(5):734-44. doi: 10.1177/1526602815601405.

3. Gandhi R, Bryce Y, Ganguli S, McWilliams J, Vatakencherry G. Management of Type II Endoleaks. [Internet]. Endovascular Today. 2016;15(4): 42-8. Available at: https://evtoday.com/pdfs/et0416_F7_Gandhi.pdf.

4. Huh U, Lee CW, Chung SW, Kim S, Song S, Bae M, et al. Risk factors of secondary intervention for type II endoleaks in endovascular aneurysm repair: An 8-year single institution study. Asian J Surg. 2017 Dec 14. pii: S1015-9584(17)30389-5. doi: 10.1016/j.asjsur.2017.10.003.

5. Eng ML, Brewer MB, Rowe VL, Weaver FA. Treatment options for late type III endoleaks after endovascular aneurysm repair. Ann Vasc Surg. 2015 Apr;29(3):594.e5-9. doi: 10.1016/j.avsg.2014.10.032.

6. Corriere MA, Feurer ID, Becker SY, Dattilo JB, Passman MA, Guzman RJ, et al. Endoleak Following Endovascular Abdominal Aortic Aneurysm Repair. Ann Surg. 2004 Jun;239(6):800-7. PMID:15166959 PMC1356288.

7. Elkouri S, Gloviczki P, McKusick MA, Panneton JM, Andrews J, Bower TC, et al. Perioperative complications and early outcome after endovascular and open surgical repair of abdominal aortic aneurysms. J Vasc Surg. 2004 Mar;39(3):497-505. doi:10.1016/j.jvs.2003.10.018.

8. Grande W, Stavropoulos SW. Treatment of Complications Following Endovascular Repair of Abdominal Aortic Aneurysms.Semin Intervent Radiol. 2006 Jun;23(2):156-64. doi:10.1055/s-2006-941446.

9. Hiramoto JS, Chang CK, Reilly LM, Schneider DB, Rapp JH, Chuter TA. Outcome of renal stenting for renal artery coverage during endovascular aortic aneurysm repair. J Vasc Surg 2009;49:1100-6. doi: 10.1016/j.jvs.2008.11.060.

10. Ignatyev IM, Volodyukhin MYu, Zanochkin AV, Gizatullina NF, Rafikov AYu. Endoprosthetic repair of an abdominal aortic aneurysm, complicated by ischaemic necrosis of the sigmoid colon. 2016;22(4):159-62. PMID: 27935896.

11. Giles KA, Landon BE, Cotterill P, O’Malley AJ, Pomposelli FB, Schermerhorn ML. Thirty-day mortality and late survival with reinterventions and readmissions after open and endovascular aortic aneurysm repair in Medicare beneficiaries. J Vasc Surg 2011;53:6-12. doi: 10.1016/j. jvs.2010.08.051.

12. Pitoulias GA, Valdivia AR, Hahtapornsawan S, Torsello G, Pitoulias AG, Austermann M, et al. Conical neck is strongly associated with proximal failure in standard endovascular aneurysm repair. J Vasc Surg. 2017 Dec; 66(6):1686-95. Epub 2017 Jun 2. doi: 10.1016/j.jvs.2017.03.440.

13. Goncalves FB, Hoeks SE, Teijink JA, Moll FL, Castro JA, Stolker RJ, et al. Risk factors for proximal neck complications after endovascular aneurysm repair using the endurant stentgraft. Eur J Vasc Endovasc Surg. 2015 Feb;49(2):156-62. doi: 10.1016/j.ejvs.2014.10.003.

14. Gargiulo M, Gallitto E, Wattez H, Verzini F, Bianchini Massoni C, Loschi D, et al. Outcomes of endovascular aneurysm repair performed in abdominal aortic aneurysms with large infrarenal necks. J Vasc Surg. 2017 Oct;66(4):1065-72. doi: 10.1016/j.jvs.2017.01.066.

15. Kouvelos GN, Oikonomou K, Antoniou GA, Verhoeven EL, Katsargyris A. A Systematic Review of Proximal Neck Dilatation After Endovascular Repair for Abdominal Aortic Aneurysm. J Endovasc Ther. 2017 Feb;24(1):59-67. doi: 10.1177/1526602816673325.

16. Litwinski RA, Donayre CE, Chow SL, Song TK, Kopchok G, Walot I, et al. The role of aortic neck dilatation and elongation in the etiology of 
stent graft migration after endovascular abdominal aortic aneurysm repair with a passive fixation device. J Vasc Surg. 2006 Dec;44(6):117681. doi:10.1016/j.jvs.2006.08.028.

17. Gallitto E, Gargiulo M, Freyrie A, Bianchini Massoni C, Pini R, Mascoli $\mathrm{C}$, et al. Results of standard suprarenal fixation endografts for abdominal aortic aneurysms with neck length $\leq 10 \mathrm{~mm}$ in high-risk patients unfit for open repair and fenestrated endograft. J Vasc Surg. 2016 Sep;64(3):563-70.e1. doi: 10.1016/j.jvs.2016.02.018.

18. Maleux G, Koolen M, Heye S. Complications after Endovascular Aneurysm Repair. Semin Intervent Radiol. 2009 Mar;26(1):3-9. doi: 10.1055/ s-0029-1208377.

19. Wu H, Liangb PC, Huang SC. The Significance of Endograft Geometry on the Incidence of Intraprosthetic Thrombus Deposits after Abdominal endovascular Grafting. Eur J Vasc Endovasc Surg. 2009 Dec;38(6):7417. doi: 10.1016/j.ejvs.2009.09.004.
20. Bartoli MA, Thevenin B, Sarlon G, Giorgi R, Albertini JN, Lerussi G, et al. Secondary procedures after infrarenal abdominal aortic aneurysms endovascular repair with second-generation endografts. Ann Vasc Surg. 2012 Feb;26(2):166-74. doi: 10.1016/j.avsg.2011.02.047.

21. Jessula S, Herman CR, Lee M, Lightfoot CB, Casey P. Salvage of bilateral renal artery occlusion after endovascular aneurysm repair with open splenorenal bypass. J Vasc Surg Cases Innov Tech. 2017 Sep;3(3):163166. doi: 10.1016/j.jvscit.2017.04.001.

22. Hamish M, Geroulakos G, Hughes DA, Moser S, Shepherd A, Salama AD. Delayed hepato-spleno-renal bypass for renal salvage following malposition of an infrarenal aortic stent-graft. J Endovasc Ther. 2010 Jun;17(3):326-31. doi: 10.1583/09-3011.1.

23. Galiñanes EL, HernandezVila EA, Krajcer Z. Innovative ChimneyGraft Technique for Endovascular Repair of a Pararenal Abdominal Aortic Aneurysm. Tex Heart Inst J. 2015 Feb;42(1):35-9. doi: 10.14503/ THIJ-14-4341. 